Anna Branach-Kallas*

\title{
(Nie)przekładalność kultur: postkolonialne porównania
}

http://dx.doi.org/10.12775/LC.2015.018

Streszczenie. Porównanie stanowi nieodzowne narzędzie badacza postkolonializmu, który opierając się na swej wiedzy i doświadczeniu, usiłuje dokonać interpretacji zjawisk będących wytworem odmiennych kodów kulturowych. W warunkach globalizacji i wielokulturowości tego typu analiza może wydawać się prostym zabiegiem interpretacyjnym. Jednakże od lat pięćdziesiątych ubiegłego stulecia zaobserwować można gruntowne transformacje procedur komparatystycznych i wartościujących w anglojęzycznej krytyce postkolonialnej. Autorka artykułu szczegółowo omawia te transformacje, stawiając pod znakiem zapytania problem przekładalności kultur. Następnie analizuje relacje intertekstualne w dwóch współczesnych utworach postkolonialnych stanowiących reinterpretację klasyki angielskiej - w Szerokim Morzu Sargassowym kreolskiej pisarki Jean Rhys zainspirowanej Jane Eyre Charlotte Brontë oraz w powieści Foe południowoafrykańskiego noblisty, Johna Maxwella Coetzee'ego, nawiązującej do Przypadków Robinsona Kruzoe Daniela Defoe. W konkluzji autorka zastanawia się nad pojęciem apropriacji kultur w dobie deterytorializacji i globalizacji, starając się zarysować twórcze horyzonty badawcze dla komparatystyki postkolonialnej.

S łow a kl u c zowe : postkolonializm; (nie)przekładalność kultur; dyskurs kolonialny; trauma; intertekstualność; wartość.

Abstract. Translating cultures?: postcolonial comparisons. Comparison is a conceptual tool often used in postcolonial studies, juxtaposing phenomena and artefacts being the products of different cultural codes. In a global and multicultural world such an analysis might seem a simple interpretative procedure. However, since the 1950s a thorough transformation of the comparative practice can be observed in English postcolonial theory and criticism. The article is an attempt to discuss these changes,

\footnotetext{
* Autorka jest adiunktem w Katedrze Filologii Angielskiej UMK. Opublikowała monografie: Uraz przetrwania. Trauma i polemika z mitem pierwszej wojny światowej w powieści kanadyjskiej (2014), Corporeal Itineraries: Body, Nation, Diaspora in Selected Canadian Fiction (2010) oraz In the Whirlpool of the Past: Memory, Intertextuality and History in the Fiction of Jane Urquhart (2003), a także liczne artykuły na temat literatury kanadyjskiej i postkolonialnej. (Współ)redagowała kilka tomów zbiorowych, w tym Niuanse wyobcowania: diaspora i tematyka polska w Kanadzie (2014). Pełni funkcje kierownika Centrum Badań Kanadyjskich przy UMK oraz wiceprzewodniczącej Polskiego Towarzystwa Badań Kanadyjskich. E-mail: kallas@umk.pl.
} 
while putting into question the problem of translating cultures. The theoretical introduction is followed by an intertextual interpretation of two contemporary postcolonial novels: The Wide Sargasso Sea by Jean Rhys, which was inspired by Charlotte Brontës Jane Eyre, and Foe by John Maxwell Coetzee, which revisions Daniel Defoe's Robinson Crusoe. The author concludes by exploring cultural appropriation in the context of deterritorialization and globalization, attempting to define new ways of approaching comparison in postcolonial studies.

Key words: postcolonialism; translating cultures; colonial discourse; trauma; intertextuality; value.

\section{Postkolonialne porównania}

orównanie - zestawienie podobieństw, uwypuklenie różnic - stanowi nieodzowne narzędzie badacza postkolonializmu, który opierając się na swej wiedzy i doświadczeniu usiłuje dokonać interpretacji zjawisk będących wytworem odmiennych kodów kulturowych. W warunkach globalizacji i wielokulturowości tego typu analiza może wydawać się prostym zabiegiem interpretacyjnym. Jednakże od lat pięćdziesiątych ubiegłego stulecia zaobserwować można gruntowne transformacje procedur komparatystycznych i wartościujących w anglojęzycznej krytyce postkolonialnej.

Okres od końca II wojny światowej do wczesnych lat siedemdziesiątych to pierwszy etap rozwoju krytyki postkolonialnej, oparty na studiach literatury w języku angielskim powstającej w krajach naznaczonych historią kolonializmu, a określanej mianem „literatury Commonwealthu”. Termin ten odnosił się do Brytyjskiej Wspólnoty Narodów, organizacji powstałej na początku XX wieku, która w połowie stulecia przekształciła się z formacji mającej na celu afirmację lojalności wobec Imperium Brytyjskiego w symboliczną wspólnotę niepodległych narodów. Pozbawiony epitetu „brytyjska”, termin „literatura Commonwealthu” był zatem teoretycznie wyrazem uznania twórczości krajów byłego Imperium za interesującą i wartościową ${ }^{1}$. Pozornie zrywał z postawą charakterystyczną dla doby kolonialnej, kiedy to literaturę obszarów Imperium uznawano za pozbawioną jakiejkolwiek wartości. Warto tu wspomnieć o słynnym tekście Thomasa Babingtona Macaulaya z 1835 roku, Minute on Indian Education, w którym autor, odpowiedzialny za reformę brytyjskiej edukacji w Indiach, przyrównuje rolę literatury angielskiej w krajach Imperium do funkcji literatury starożytnej Grecji i starożytnego Rzymu w dobie europejskiego renesansu, a literaturę w sanskrycie określa jako mniej wartościową niż dzieła angielskiego średniowiecza². Tego typu porównania miały na celu nie tylko dewaluację dziedzictwa kulturowego narodów podbitych

1 J. McLeod, Beginning Postcolonialism, Manchester-New York 2000, s. 10-12.

2 T. Macaulay, Minute on Indian Education, [w:] The Post-colonial Studies Reader, red. B. Ashcroft, G. Griffiths, H. Tiffin, London-New York 1999, s. 429. 
oraz potwierdzenie rangi kultury brytyjskiej jako autorytatywnej miary wszelkich wartości estetycznych i intelektualnych. Mamy tu bez wątpienia do czynienia $\mathrm{z}$ formowaniem się swoistego kanonu, w którym literatura angielska pełni funkcję nadrzędną, negując wartość twórczości tzw. barbarzyńców. Macaulay jednak przypisuje literaturze angielskiej również rolę moralizatorską i polityczną: za jej pośrednictwem Imperium przekazywało zachodnie wartości mieszkańcom podbitych lądów, konstruując obraz kultury europejskiej jako kultury nadrzędnej, co służyło podtrzymaniu autorytetu białego człowieka oraz władzy kolonialnej. Angielski system oświaty miał zatem kształcić rdzenną ludność w taki sposób, by zamieniała się w „Anglików, jeśli chodzi o gust, poglądy, morale i intelekt”. Macaulay wprowadził więc hierarchię, w której literatura angielska staje się „normatywnym ucieleśnieniem piękna, prawdy i zasad moralnych, czyli innymi słowy - tekstualnym standardem, który skolonizowane kultury i ich książki stygmatyzuje jako marginalne i gorsze"4. W tym świetle sposób postrzegania rzeczywistości stworzony przez ekspansję kolonialną wyklucza inne sposoby rozumienia świata i funkcjonowania w nim. Kolonializm zatem opiera się nie tylko na ekspansji terytorialnej, lecz również na kolonizacji wyobraźni, a „dekolonizacja umysłu"s, którą można zinterpretować jako swoiste wyzwolenie kolonizowanego z rządów nieustannego porównania, jest zadaniem niezwykle trudnym i mozolnym. Choć termin „literatura Commonwealthu” miał określać twórczość autorów z różnych zakątków świata, nie wprowadzając między nimi hierarchii wartości, w rzeczywistości jednak uważano, że pisarzy tych łączy wspólne dziedzictwo kulturowe, a odbiorcą pisanych przez nich tekstów powinien być anglojęzyczny czytelnik Zachodniej Europy. Kryteria oceny stosowane przez krytyków tej literatury opierały się na tzw. wartościach uniwersalnych, uznając za punkt odniesienia kanon literatury angielskiej, co stanowi technikę komparatystyczną nie tak odległą od propozycji Macaulaya. Szczegóły natury historycznej, geograficznej i kulturowej oceniano w tych utworach jako elementy drugorzędne, nadające im tylko ciekawy, egzotyczny koloryt. Natomiast wartości uniwersalne i ponadczasowe, ugruntowane w tradycji literatury angielskiej, miały stanowić o wartości literatury Commonwealthu' ${ }^{6}$.

Teorie dyskursu kolonialnego, a przede wszystkim opublikowany w roku 1978 Orientalizm wykształconego w USA Palestyńczyka, Edwarda W. Saida, to początek nowego etapu w studiach postkolonialnych ${ }^{7}$. Teza Michela Foucaulta, zgodnie z którą wiedza jest fundamentem władzy, legła u podstaw dzieła Saida, będącego studium zachodnioeuropejskich reprezentacji kultur Bliskiego Wschodu. Interpretacja kolonializmu jako dyskursu, czyli swoistej wyobrażeniowej struktury myślowej wyłaniającej się z tekstów tak różnych, jak traktaty polityczne, dzieła naukowe, literatura piękna, malarstwo, mapy, praktyki medyczne czy moda, umożliwiła wnikliwą analizę ukrytych czynników kształtujących kultury i procedery imperialne. Dzieło Saida nadało nowy, bardziej teoretyczny kształt studiom nad kolonializmem, które rozwinęły się w latach osiemdziesiątych, obalając granice pomiędzy

3 Ibidem, s. 430 (tłumaczenie A.B.-K.). Jak silna była tradycja literaturoznawstwa angielskiego i narzuconych przez nie porównań, udowadniają liczni pisarze i myśliciele postkolonialni. Zob. J. Kincaid, A Small Place, New York 1988; Ngũgĩ wa Thiong'o, Decolonising the Mind: The Politics of Language in African Literature, London 1986; G. Lamming, The Pleasures of Exile, London 1960.

${ }^{4}$ L. Gandhi, Teoria postkolonialna. Wprowadzenie krytyczne, tłum. J. Serwański, Poznań 2008, s. 130.

${ }_{5}$ "Decolonising the mind" to termin wprowadzony przez kenijskiego krytyka i pisarza Ngũgĩ wa Thiong'o, op. cit.

6 J. MacLeod, op. cit., s. 12-16; Ch. Achebe, Colonialist Criticism, [w:] The Post-colonial Studies Reader, s. 57-61.

7 E. W. Said, Orientalizm, tłum. M. Wyrwas-Wiśniewska, Poznań 2005. 

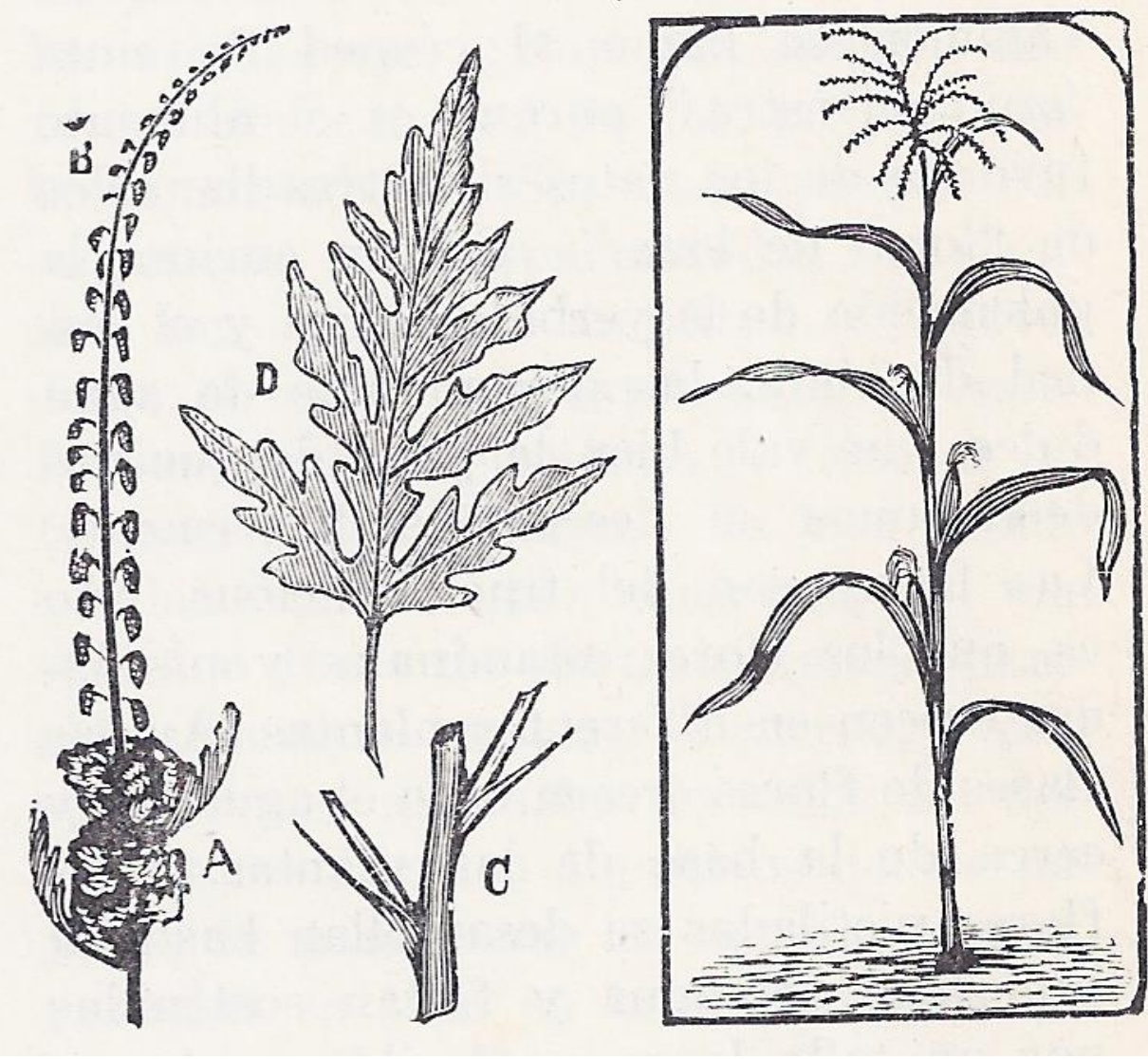

dziedzinami wiedzy do tej pory uznawanymi za niekompatybilne, takimi jak literaturoznawstwo, etnologia, antropologia, psychoanaliza, socjologia czy politologia. Ten przełom teoretyczny w znaczący sposób wzbogacił warsztat badacza postkolonialnego oraz spektrum stosowanych metod komparatystycznych.

Ważne tezy Orientalizmu - takie jak wyobrażeniowy charakter zachodnioeuropejskich reprezentacji Orientu, wpływ kolonializmu na rozwój europejskiej cywilizacji, a przede wszystkim nauki i sztuki, ideologiczne i głęboko ukryte podstawy kolonializmu oparte na stereotypach i różnych kategoriach wykluczenia - wynikają z fundamentalnej idei Saida, zgodnie z którą orientalizm stanowi wizję rzeczywistości wspartą na binarnej opozycji pomiędzy Zachodem a Wschodem, tym, co znane i swojskie, a tym, co nieznane i obce. Orient jest zatem tym wszystkim, czym nie jest Zachód lub czym Zachód być nie pragnie. W ujęciu komparatystycznym Said postrzegał relację pomiędzy Wschodem a Zachodem jako całkowanie asymetryczną. Jego zdaniem kolonizatorzy stworzyli pozytywny, wyidealizowany obraz kultury zachodniej i białego człowieka, przypisując ludom i kulturom Orientu wszelkie cechy negatywne w zakresie etyki, intelektu, konstrukcji płci, czy też estetyki. Dobro, piękno, inteligencja, racjonalność, umiar to zatem atrybuty białego człowieka, podczas gdy zło, brzydota, ignorancja, irracjonalność, agresja to cechy mieszkańca kolonii. Ujmując rela- 
cję Zachód-Wschód jako binarną opozycję pomiędzy cywilizacją a barbarzyństwem, Said $\mathrm{z}$ jednej strony interpretuje kultury w kategoriach różnicy absolutnej - ilustrując metody poznawcze i porządkujące kolonizatorów, w których porównanie staje się zabiegiem prostym i transparentnym. Pożytki takiego porównania są oczywiste - ma ono na celu ułatwienie wyzysku i kontroli ludów skolonizowanych. Z drugiej jednak strony Orientalizm ukazuje, że imperializm opierał się w zasadzie na przekonaniu o nieprzekładalności kultur, sytuującym porównanie w sztywnych ramach - my/oni - i uniemożliwiającym wnikliwe spojrzenie komparatystyczne. Kontynuatorzy Saida stosowali ten prosty schemat do badań nad literaturą i kulturą kolonialną, często dokonując swoistego odwrócenia etycznych dychotomii, mnożąc klisze i stereotypy.

W późniejszych tekstach Said zwraca uwagę na bardziej zróżnicowany charakter relacji pomiędzy kolonizatorami a mieszkańcami kolonii. W dziele Kultura i imperializm (1993) proponuje metodę „czytania kontrapunktowego”, które uwzględni różne doświadczenia historyczne, perspektywy epistemologiczne oraz interakcje pomiędzy koloniami a metropolią․ Z kolei Mary Louise Pratt wprowadza pojęcie „strefy kontaktu” dla określenia zróżnicowanej przestrzeni społecznej kolonii, przestrzeni spotkań i tarcia różnych kultur, „współobecności, interakcji, zazębiającego się rozumienia i działania, często też w obrębie skrajnie asymetrycznych stosunków sił". Omawiając popularne w Zachodniej Europie drugiej połowy XIX wieku systemy klasyfikowania istot ludzkich oparte na szczegółowych pomiarach czaszki, żuchwy, zębów, uszu, nosa, dłoni, nóg, wagi mózgu itp., badacze tacy jak Anne McClintock, Nancy Leys Stepan, czy też Sander L. Gilman ${ }^{10}$ porównują podobieństwa w dyskursach rasy, klasy, płci, norm przyzwoitości i orientacji seksualnej, dyskursach, których celem było sprawowanie kontroli zarówno w kolonii, jak i w stolicy Imperium. Udowadniają $\mathrm{w}$ ten sposób współdziałanie różnych ideologii w kształtowaniu nowoczesności. Homi K. Bhabha i Abdul R. JanMohamed w swoich pracach ${ }^{11}$ wykazali ambiwalentny charakter stereotypów kolonialnych i popularnej w dobie imperializmu alegorii manichejskiej. Obaj uwypuklili rolę lęku oraz poczucia chaosu i zagrożenia w stosunku kolonizatorów do ludów skolonizowanych, a także kompulsywny charakter stereotypów. Zdaniem tych krytyków, przedstawiciele Imperium, porównując się do rdzennych mieszkańców kolonii, odczuwali zatem nie tylko satysfakcję, płynącą z poczucia wyższości i dominacji. Ich uczucia były znacznie bardziej ambiwalentne, a fałszywy, stereotypowy obraz Ja i Innego był wynikiem przemieszczenia poczucia winy i agresji, wypartego niepokoju i pożądania, ukrytych fobii i fantazji. Dla wspomnianych badaczy porównanie jest zatem złożonym zabiegiem analitycznym, uwzględniającym wielorakie płaszczyzny dominacji i subordynacji.

\footnotetext{
${ }^{8}$ E. Said, Kultura i imperializm, tłum. M. Wyrwas-Wiśniewska, Kraków 2009. Zob. również D. Kołodziejczyk, Wojna światów? Postkolonialny kontrapunkt w nowej komparatystyce, „Teksty Drugie” 2014, nr 4.

9 M. L. Pratt, Imperialne spojrzenie: pisarstwo podróżnicze a transkulturacja, tłum. E. E. Nowakowska, Kraków 2011, s. 27.

10 A. McClintock, Imperial Leather: Race, Gender and Sexuality in the Colonial Contest, New York-London 1995; N. L. Stepan, Race and Gender: The Role of Analogy in Science, [w:] Anatomy of Racism, red. D. T. Goldberg, Minneapolis-London 1990, s. 38-57; S. L. Gilman, Black Bodies, White Bodies: Toward an Iconography of Female Sexuality in Late Nineteenth-Century Art, Medicine, and Literature, [w:] "Race", Writing, and Difference, red. H. L. Gates, Jr., Chicago-London 1986.

11 H. K. Bhabha, Miejsca kultury, tłum. T. Dobrogoszcz, Kraków 2010; A. R. JanMohamed, The Economy of Manichean Allegory: The Function of Racial Difference in Colonialist Literature, [w:] „Race”, Writing, and Difference.
} 
Poszerzający się wachlarz problemów i obszarów badawczych wpłynął na krytyczne podejście do metodologii postkolonialnych samych badaczy postkolonializmu. Zwrócono uwagę na fakt, że czynników kształtujących kultury obszarów tak odmiennych jak Afryka, Indie, Kanada czy Australia nie można porównywać i wymagają one zupełnie innego ujęcia teoretycznego. Kategorie różnicujące, takie jak Pierwszy Świat, Drugi Świat (tzw. kolonie osiedleńcze - Kanada, Australia, RPA, Nowa Zelandia), Trzeci Świat oraz Czwarty Świat (ludność tubylcza w koloniach osiedleńczych), pozwoliły wprawdzie wyodrębnić różne rodzaje kolonialnej opresji i oporu, nie wydają się jednak one w pełni satysfakcjonujące ${ }^{12}$. Ryzykowne zrównanie postkolonializmu z postmodernizmem również budzi liczne kontrowersje ${ }^{13}$. Ponadto samo rozumienie terminu „postkolonializm” jest kwestią sporną. Czy należy go rozumieć w sensie geograficznym - w odniesieniu do krajów byłego Imperium, w sensie historycznym - jako określenie dotyczące historii pewnych obszarów świata po upadku mocarstw kolonialnych, czy też jako swoistą metodę interpretacji, która może łączyć teoretyków i pisarzy na całym świecie? Dla wielu myślicieli wywodzących się ze społeczności indiańskich ${ }^{14}$ termin „postkolonializm” jest pozbawiony sensu i ryzykowny z punktu widzenia etycznego, gdyż uważają oni, że nadal żyją w społeczeństwie skolonizowanym, a teoretyczne różnice między tzw. dobą kolonialną a postkolonialną tylko uwypuklają eurocentryzm stosowanych porównań.

Interesującym, stosunkowo nowym kierunkiem rozwoju wydaje się zastosowanie w badaniach postkolonialnych teorii traumy oraz pamięci, wywodzących się ze studiów nad Holokaustem. Takie interpretacje nie opierają się na mechanicznym porównaniu, lecz mają na celu uwypuklenie działania w różnych kontekstach historycznych i geograficznych podobnej logiki rasizmu i zagłady, logiki charakterystycznej dla nowoczesności ${ }^{15}$. Doświadczenie Holokaustu nie traci w ten sposób swej traumatycznej wyjątkowości, nie zostaje bowiem zrównane z innymi przykładami zagłady, lecz sytuowane jest w pewnej sieci zbieżności i asymetrii, pamięci i niepamięci, konfliktów i solidarności ${ }^{16}$. W tym świetle doświadczenie kolonializmu można interpretować w kategoriach traumy zbiorowej, a postkolonializm rozumieć jako posttraumatyczną strukturę kulturową ${ }^{17}$. Jeśli przyjąć tezę Cathy Caruth, jednej z czołowych przedstawicielek trauma studies, że trauma stanowi swoisty most łączący różne kultury ${ }^{18}$, to można dojść do wniosku, iż traumatyczne doświadczenia europejskie są ściśle powiązane z uciskiem kolonialnym w innych częściach świata. Zestawienie rzekomo odrębnych kontekstów przemocy prowadzi do nowego odczytania każdego z nich. Snując refleksję nad dotychczasowym

12 Zob. S. Slemon, Unsettling the Empire: Resistance Theory for the Second World, [w:] The Post-colonial Studies Reader, s. 104-110; A. Loomba, Kolonializm/postkolonializm, tłum. N. Bloch, Poznań 2011, s. 212-214.

13 Zob. część IV pt. Postmodernism and Post-colonialism, [w:] The Post-colonial Studies Reader, s. 117-147.

14 Zob. T. King, Godzilla vs. Post-Colonial, [w:] Unhomely States: Theorizing English-Canadian Postcolonialism, red. C. Sugars, Toronto 2004.

15 Zob. również D. Kołodziejczyk, Postkolonialne odzyskiwanie pamięci: zawłaszczenia, fabulacje, niesamowite dopominanie, [w:] Od pamięci biodziedzicznej do postpamięci, red. T. Szostek, R. Sendyka i R. Nycz, Warszawa 2013, s. 283-287.

${ }^{16}$ Przykładem tego typu interpretacji może być przeprowadzona przeze mnie analiza porównawcza traumy w kontekście I wojny światowej oraz opresji kolonialnej i zagłady Indian w Ameryce Północnej. Zob. A. Branach-Kallas, Świadectwo Innego - Three Day Road Josepha Boydena, [w:] Uraz przetrwania. Trauma i polemika z mitem pierwszej wojny światowej w powieści kanadyjskiej, Toruń 2014

17 S. Craps i G. Buelens, Introduction: Postcolonial Trauma Novels, "Studies in the Novel" 2008, t. 40, nr $1 / 2$, s. 2 .

${ }_{18}$ C. Caruth, Trauma and Experience: Introduction, [w:] Trauma: Explorations in Memory, red. C. Caruth, Baltimore-London 1995, s. 11. 
wykluczeniem badań postkolonialnych ze studiów nad pamięcią, Michael Rothberg postuluje konieczność wypracowania wielokierunkowej, transkulturowej etyki porównania, opartej na przyjęciu odpowiedzialności za wydarzenia historyczne, których dany podmiot nie uznaje automatycznie za „własne” ${ }^{19}$. Stef Craps i Gert Buelens, pionierzy badań nad traumą postkolonialną, uwypuklają konieczność wydobycia z cienia pozaeuropejskich wydarzeń traumatycznych ${ }^{20}$, zauważają jednak zarazem ryzyko porównań w świetle eurocentrycznych teori, a co za tym idzie, konieczność zredefiniowania samego pojęcia urazu w kontekście różnych kultur postkolonialnych, w których afekty związane z przeżyciem traumatycznym mogą kształtować się inaczej ${ }^{21}$. Również Gayatri Chakravorty Spivak podkreśla, jak trudne, często wręcz niemożliwe jest odwrócenie perspektywy, wsłuchanie się w głos Innego w postulowanych przez nią „nowych” badaniach komparatystycznych na miarę XXI wieku ${ }^{22}$.

\section{Porównanie z klasyką: postkolonialne „przepisywanie”}

Reinterpretacja klasyki brytyjskiej oraz szeroko rozumiana intertekstualność - gra podobieństw i różnic na wielu poziomach - stanowią istotne elementy literatury postkolonialnej. Szerokie Morze Sargassowe, wydana w 1966 roku powieść Jean Rhys (1890-1979), białej pisarki wychowanej na Dominikanie, nawiązuje do Jane Eyre - klasycznego Bildungsroman Charlotte Brontë z 1847 roku $^{23}$. Związek intertekstualny pomiędzy utworami Brontë a Rhys można interpretować jako amplifikację czyli, cytując Laurenta Jenny, „przekształcenie tekstu pierwotnego przez rozwinięcie jego wirtualności semantycznych"24, bowiem Szerokie Morze Sargassowe pozornie stanowi tzw. prequel, czyli opowieść o wydarzeniach poprzedzających akcję Jane Eyre. Istotny jest jednak aspekt ideowy powieści - Rhys nie interesuje zwykłe zapożyczenie, cytat z wielkiej klasyki angielskiej, zawoalowana aluzja erudytki, leczpolemika z tekstem klasycznym. Nie jest to również przykład postmodernistycznej parodii świadczącej o wyczerpaniu możliwości literatury europejskiej, która przetrwać może jedy-

19 M. Rothberg, Między Paryżem a Warszawą. Pamięć wielokierunkowa, etyka i odpowiedzialność historyczna, tłum. T. Bilczewski i A. Kowalcze-Pawlik, [w:] Od pamięci biodziedzicznej, s. 178. Co ciekawe, Rothberg umieszcza w polu swej analizy nie tylko historie postimperialne i postnarodowo-socjalistyczne, lecz również postkomunistyczne i postmigracyjne.

20 S. Craps i G. Buelens, op. cit., s. 1-12.

21 Ibidem, s. 4.

22 Zob. G. Ch. Spivak, Death of a Discipline, New York-Chichester 2003. Spivak pisze tu o narodzinach nowej komparatystyki, która obejmie nie tylko badania nad kulturą diaspor, postulat wielokulturowości, lecz również otworzy się na "starsze" mniejszości - z Afryki, Azji oraz Ameryki Łacińskiej. Ważną rolę w tych "nowych" badaniach komparatystycznych powinna także odegrać postkolonialność byłego bloku sowieckiego, a także wpływ islamu na kulturę globalną. Badaczka wątpi jednak, czy, w odróżnieniu od wykształconego emigranta, pozbawiony dostępu do edukacji, nieznający dominujących języków europejskich mieszkaniec odległych od metropolii terytoriów może się stać po d m i o t e m takich badań. Spojrzeć na literaturę porównawczą oczami Innego to nowe zadanie dla tej radykalnej komparatystyki. Zob. również G. Ch. Spivak, Komparatystyka ekstremalna, tłum. D. Kołodziejczyk, „Recykling Idei” 2008, nr 10 (wiosna/lato), s. 130-132.

${ }^{23}$ Ch. Brontë, Jane Eyre, Harmondsworth 1962; wydanie polskie: Jane Eyre, tłum. T. Świderska, Warszawa 2011. J. Rhys, Wide Sargasso Sea, London 1966; wydanie polskie: Szerokie Morze Sargassowe, tłum. M. Topczewska-Metelska, Kraków 1987.

${ }^{24}$ L. Jenny, Strategia formy, tłum. K. i J. Faliccy, „Pamiętnik Literacki” 1988, z. 1, s. 288. 
nie poprzez symulakra i zapożyczenia ${ }^{25}$. Rhys pragnie bowiem przetworzyć i na nowo zdefiniować dawne znaczenia, tak aby stworzyć nowy sens, który umożliwi krytyczne spojrzenie na dzieło Brontë.

W powieści Rhys zasadniczą rolę odgrywa Antoinette/Berta, zainspirowana drugoplanową postacią Berty Mason, stworzoną przez Charlotte Brontë w Jane Eyre. W oryginalnym tekście Berta jest Kreolką, którą Rochester poślubił dla posagu w czasie pobytu na Jamajce. Jej skrytą obecność w mrocznym domostwie Rochestera zdradzają krzyki i dziki, niepokojący śmiech. Wyjawienie jej istnienia uniemożliwia małżeństwo Jane z Rochesterem, którzy dopiero po śmierci jego pierwszej żony mogą się połączyć. W swojej spowiedzi wobec niedoszłej małżonki Rochester wyznaje, że poślubił Bertę na skutek spisku i że cała jej rodzina składa się z alkoholików i szaleńców. Sama Jamajka jest opisana przez Rochestera niczym piekło na ziemi, w którym bohater prawie uległ pokusie samobójstwa. Natomiast w narracji Jane spotkanie z Bertą przedstawione jest jako moment grozy: postać ta porusza się na czworakach, jak zwierzę, skowyczy i jęczy, jest agresywna wobec „normalnych” ludzi ${ }^{26}$. Co ciekawe, kolor skóry Berty jest w powieści bardzo dwuznaczny, co łączy się z niejasnością terminu „Kreol” - w XIX wieku oznaczał on bowiem osobę urodzoną w kolonii lub osobę mieszanej rasy ${ }^{27}$. Jej twarz jest blada niczym oblicze ducha, purpurowa jak u pijaczki, czarna i opuchnięta jak u Murzynki. Opisy Berty charakteryzuje ponadto duża doza niepewności, zastanawiająca u asertywnej, wszechwiedzącej narratorki, jaką na ogół jest Jane.

Tożsamość Berty pozostaje więc aporią Jane Eyre, aporią, którą Rhys wykorzystuje w Szerokim Morzu Sargassowym. Podczas gdy w powieści Brontë to postać Berty kreuje atmosferę grozy i niepewności, w Szerokim Morzu Sargasowym źródłem lęku staje się dynamika rasowa w społeczeństwie kolonialnym oraz konfrontacja odmiennych kodów kulturowych. Antoinette i jej matka Berta jako potomkinie rodzin bogatych plantatorów budzą nienawiść (byłych) niewolników, nie są jednak także w pełni akceptowane przez elitę europejską. Społeczeństwo Jamajki pierwszej połowy XIX wieku ukazane jest jako świat barier i sztucznych dychotomii opartych na podziałach rasowych. Postaci Kreola i Mulata, których przynależność rasowa jest nieustannie kwestionowana w powieści, przekraczają te sztuczne granice i podważają rację ich bytu. Po śmierci ojca Antoinette jej matka, Berta, staje się ofiarą ostracyzmu białych osadników ze względu na niejasne pochodzenie. Dla czarnych robotników natomiast zubożała rodzina Coswayów podlega degradacji ze względu na utratę majątku i prestiżu. Jednak prawdziwą przyczyną alienacji rodziny bohaterki jest nieczystość rasowa Kreolów. Kreol umiejscowiony jest zatem w omówionej przez Julię Kristevą ${ }^{28}$ kategorii abiektu - wyparcia z obrzydzeniem - jest kimś niechcianym, ohydnym, wstrętnym wybrykiem natury. Powracający w Szerokim Morzu Sargasowym motyw lustrzanego odbicia oddaje ambiwalencje tożsamościowe bohaterki, zagubionej pomiędzy grupą białych kolonizatorów i czarnych (potomków) niewolników ${ }^{29}$.

25 Por. J. Barth, The Literature of Exhaustion, [w:] The Novel Today: Contemporary Writers on Modern Fiction, red. M. Bradbury, Glasgow 1977.

${ }^{26} \mathrm{Na}$ dehumanizację postaci Berty Mason w powieści Brontë, motyw odzyskania przez nią człowieczeństwa w powieści Rhys, a także uwikłania imperialne w konstrukcji tożsamości bohaterek obu powieści oraz konieczność ich reinterpretacji zwróciła uwagę Gayatri Chakravorty Spivak w Three Women's Texts and a Critique of Imperialism, [w:] „Race”, Writing.

27 S. L. Meyer, From "Colonialism and the Figurative Strategy of Jane Eyre”, [w:] Post-Colonial Theory and English Literature, red. P. Childs, Edinburgh 1999, s. 151-152.

28 J. Kristeva, Potęga obrzydzenia. Esej o wstręcie, tłum. M. Falski, Kraków 2007.

29 G. Ch. Spivak, Three Women's, s. 269. 
Najistotniejszym elementem polemiki intertekstualnej z Jane Eyre w Szerokim Morzu Sargassowym jest motyw szaleństwa Antoinette i jej matki Berty. Histeria i depresja, w którą popada Berta po utracie syna i plantacji, wydają się czytelnikowi w pełni zrozumiałe, dla jej męża Masona stanowią jednak pretekst do izolacji żony. Podobnie dorosła już Antoinette zostaje zamknięta przez swojego męża - bezimiennego bohatera, którego czytelnik obeznany z Jane Eyre nazywa Rochesterem - gdy popada w depresję i alkoholizm na skutek odrzucenia przez ukochanego. Piękna, zmysłowa, lecz bardzo odmienna od europejskich kobiet Antoinette budzi lęk bohatera, zadufanego w sobie mężczyzny przekonanego o swojej wyższości rasowej i płciowej. Kiedy pod jej wpływem doznaje on głębokiej przemiany, tracąc rozsądek i samokontrolę, namiętność i własna metamorfoza, za które wini Antoinette, wywołują w nim odrazę i przerażenie. Utratę równowagi psychicznej ilustruje również jego percepcja krajobrazu karaibskiego: wrogość, jaką przypisuje otaczającej go przyrodzie, a także niepokojące szepty i ruchy natury wprowadzają go w stan zagrożenia, który można zinterpretować jako wyraz alienacji w zupełnie obcym mu kraju. Magiczne praktyki obi, którym poddaje go służąca Christophine na skutek próśb Antoinette, chcącej w ten sposób odzyskać miłość męża, potęgują histeryczne pragnienie ucieczki bohatera. Skomplikowana narracja powieści, w której głosy bohaterów splatają się ze sobą, wprowadza czytelnika w stan niepewności, kreując atmosferę halucynacji i dwuznaczności. Walcząc o odzyskanie kontroli nad sobą i otoczeniem, Rochester nazywa Antoinette Bertą, zamieniając ją w ten sposób, niczym mag obi, we własną matkę, i zabiera ją do Anglii. Refleksje zrozpaczonej bohaterki, uwięzionej przez męża pod koniec powieści w angielskim dworze, pogłębiają niepewność czytelnika co do źródeł i charakteru szaleństwa oraz potworności w powieści.

Co istotne, porównanie dzieła Rhys z angielskim pierwowzorem wplywa na przemyślenie pierwowzoru przez czytelnika. Podczas gdy w Jane Eyre Rochester przedstawia się jako ofiara Berty i jej rodziny, w Szerokim Morzu Sargassowym Antoinette/Berta zostaje ubezwłasnowolniona przez swego męża na skutek jego zazdrości lub obłąkania. Motyw histerii, przez stulecia interpretowanej jako przypadłość czysto kobieca ${ }^{30}$, kwestionuje na pozór oczywistą dychotomię pomiędzy równowagą psychiczną a jej utratą w Jane Eyre. Zestawienie obu powieści podważa wiarygodność Rochestera w powieści Brontë i sugeruje, że ważką rolę w jego stosunku do pierwszej żony odegrały uprzedzenia kolonialne. Ponadto tarcie XIX-wiecznych ideałów męskości i kobiecości, uwypuklone w Szerokim Morzu Sargassowym, pozwala czytelnikowi spojrzeć bardziej wnikliwie na konstrukcję płci w powieści Brontë i uzmysłowić sobie złożoną dynamikę społeczno-kulturową, której produktem była Jane Eyre. Co więcej, problematyka kreolska zgłębiona przez Rhys stawia postać Berty z dzieła Brontë w zupełnie innym świetle. Związek Berty z ogniem, który traktuje ona jako swoistą broń, podpalając łóżko swojego męża, a w końcu i jego posiadłość, można zinterpretować w odniesieniu do buntów niewolników na Jamajce, które wybuchały w latach trzydziestych XIX wieku, a jest to czas akcji Jane Eyre. Pożar plantacji oznajmiał wówczas przejęcie kontroli przez rebeliantów ${ }^{31}$. Zanalizowana w tym świetle powieść Brontë daje więc wyraz konserwatywnej lojal-

30 Zob. J. Lewis Herman, Przemoc. Uraz psychiczny i powrót do równowagi, tłum. A. i M. Kacmajor, Gdańsk 2007, s. 20-30; S. Bordo, Unbearable Weight: Feminism, Western Culture and the Body, Berkeley-Los Angeles-London 1995 , s. 168-170.

31 J. McLeod, op. cit., s. 158. Wspomniane czynniki historyczne pozwalają zinterpretować czyn Antoinette/Berty w kategoriach sprawstwa, a nie aktu poświęcenia mającego na celu gloryfikację kultury imperialnej. W tym świetle samobójstwo Berty Mason w Jane Eyre odczytuje G. Ch. Spivak w A Critique of Postcolonial Reason: Toward a History of the Vanishing Present, Cambridge-London 1999, s. 127. W odróżnieniu od dekon- 
ności autorki wobec kolonializmu, odsłania jednak również jej zawoalowany dystans wobec dominującej ideologii imperialnej ${ }^{32}$. Lektura powieści Rhys pozwala także zreinterpretować zakończenie Jane Eyre. Wezwana telepatycznie przez zrujnowanego, okaleczonego, oślepłego Rochestera, Jane błąka się po lesie przepełnionym wilgotną, gęstą mgłą. Ta ciężka, niepokojąca atmosfera towarzysząca spotkaniu kochanków sugeruje, że świat przedstawiony nie został w pełni oczyszczony przez śmierć Berty. Wszak fortuna odziedziczona przez Jane, która umożliwia jej ślub z Rochesterem, ma także podłoże kolonialne: jej zmarły wuj był agentem pośredniczącym w handlu niewolnikami na Maderze ${ }^{33}$.

Perspektywa komparatystyczna prowadzi jednak do odkrycia pewnej niespójności chronologicznej, która stawia koherentność przedstawionej interpretacji pod znakiem zapytania. Wszak tekst Rhys wydaje się snuć opowieść o wydarzeniach poprzedzających losy bohaterów Jane Eyre, jednak daty, które pojawiają się w narracji, sugerują, że akcja powieści Rhys rozgrywa się po zakończeniu powieści Brontë ${ }^{34}$. To zaburzenie chronologiczne wzmacnia przesłanie wyłaniające się z konstrukcji tekstu Rhys, w którym każdy z bohaterów usiłuje narzucić czytelnikowi swój punkt widzenia. Rhys sprzeciwia się w ten sposób interpretacji swej powieści w odniesieniu do Jane Eyre, sprzeciwia się sztywnym ramom porównania, które sytuuje dzieło należące do kanonu brytyjskiego w pozycji nadrzędnej wobec jej własnego utworu. Rhys uwypukla również w ten sposób aktywną rolę czytelnika, który wraz z nią „przepisuje” Jane Eyre. Pojawia się jednak pytanie, kim jest idealny odbiorca jej powieści ${ }^{35}$. Jedynie wykształcony czytelnik jest w stanie rozpoznać w bohaterze Rhys Rochestera Charlotte Brontë, a nieznajomość klasyki brytyjskiej zapewne prowadziłaby do zupełnie innej analizy zachowań bezimiennej postaci. Ponadto porównanie narracji obu powieści - opowieści wszechwiedzącej Jane z chaosem narracyjnym w Szerokim Morzu Sargassowym - uświadamia czytelnikowi subiektywność percepcji i interpretacji, której przeczy autorytatywny głos bohaterki-narratorki w Jane Eyre.

W opublikowanej w 1986 roku powieści Foe południowoafrykański noblista, John Maxwell Coetzee (ur. 1940) dokonuje swoistej reinterpretacji klasycznej powieści Daniela Defoe z 1719 roku Przypadki Robinsona Kruzoe ${ }^{36}$, uznanej za pierwszą powieść napisaną w języku angielskim. Coetzee przedstawia przygodę Robinsona na bezludnej wyspie w sposób bardziej realistyczny, korygując jak gdyby wstępną wersję Defoe: na przykład bohaterowi Coetzee'ego udaje się uratować znacznie mniej przedmiotów z wraku statku, co wpływa na bardziej prymitywne warunki życia na wyspie. Poprzez przedstawienie niebywałego sukcesu Robinsona, który samodzielnie buduje prawdziwe królestwo na bezludnej wyspie, powieść Defoe stanowi przykład propagandy imperialnej, mającej na celu zachęcenie Brytyjczyków do ekspansji kolonialnej ${ }^{37}$, a także wyraz idealizacji nowego, przedsiębiorczego

strukcjonistycznych refleksji tej badaczki, w przedstawionej tu analizie pragnę skupić się na tekstualnej transformacji konkretnych wątków i motywów w powieściach Brontë i Rhys, a następnie Defoe i Coetzee'ego.

32 S. L. Meyer, op. cit., s. 150.

33 J. McLeod, op. cit., s. 151.

${ }^{34}$ Akcja powieści Rhys osadzona jest w latach trzydziestych i czterdziestych XIX wieku, podczas gdy Jane Eyre kończy się w połowie lat trzydziestych. Opisując relację pomiędzy Szerokim Morzem Sargassowym a Jane Eyre, McLeod określa powieść Rhys za pomocą oksymoronu „post-dated prequel”. McLeod, op. cit., s. 166.

35 Zob. J. McLeod, op. cit., s. 167-169.

${ }^{36}$ D. Defoe, The Life and Adventures of Robinson Crusoe, Harmondsworth 1985; wydanie polskie: Przypadki Robinsona Kruzoe, tłum. J. Birkenmajer, Wrocław 2002. J. M. Coetzee, Foe, New York 1987; wydanie polskie: Foe, tłum. M. Konikowska, Kraków 2007. Odwołania w artykule do tłumaczenia na język polski.

37 R. Phillips, Mapping Men and Empire: A Geography of Adventure, London 1997. 
człowieka doby oświecenia, którego postępowanie jest racjonalne, celowe i pożyteczne. Jak zaznacza Gayatri Chakravorty Spivak, w odróżnieniu od swego pierwowzoru, bohater Foe nie pragnie stać się prężnym kapitalistą, nie wykazuje więc zainteresowania gromadzeniem i pomnażaniem kapitału ${ }^{38}$. Coetzee obala utopijną wizję Defoe, kreując postać biernego, niezaradnego Kruzo, którego czynności pozbawione są sensu, i podważając w ten sposób ideał racjonalnego kapitalisty czasów oświecenia. Co istotne, w powieści Defoe niezwykle ważną rolę odgrywa wpleciony w narrację dziennik Robinsona jako przykład rozwijającego się w XVIII wieku purytańskiego pamiętnikarstwa, stanowiącego narrację o nawróceniu. Podczas gdy pomoc Opatrzności wysuwa się na pierwszy plan w Przypadkach Robinsona Kruzoe, rozbitek Coetzee'ego wątpi w jej istnienie. Nie pragnie powrotu do ojczyzny, a kiedy zostaje siłą zabrany na pokład przybyłego okrętu, umiera z tęsknoty za utraconym królestwem. Coetzee prowadzi w ten sposób polemikę z XVIII-wiecznym konceptem człowieka cywilizowanego, w którym kontakt z naturą budzi przemożny lęk i który, jak Robinson Defoe, pragnie nade wszystko kontaktu $\mathrm{z}$ innymi ludźmi.

Niezwykle interesujący w postmodernistycznej powieści Coetzee'ego jest problem obiektywizmu, głosu narracyjnego oraz konwencji literackich. Problematyka ta stanowi wnikliwy komentarz do powieści Defoe, do kształtującej się w XVIII wieku tradycji realizmu oraz przemilczeń i pominięć charakterystycznych dla patriarchatu i imperializmu. W przeciwieństwie do systematycznego Robinsona Kruzoe, bohater Foe nie prowadzi żadnych zapisków ani kalendarza, negując głęboki indywidualizm swego pierwowzoru, twierdząc, że nic z tego, co zapomniał, nie byłoby warte zapamiętania ${ }^{39}$. Przedstawia różne, często niespójne wersje swoich przygód, co podważa obiektywność popularnych w Europie narracji wczesnych podróżników. Komentarze Kruzo Coetzee’ego uwypuklają również sztuczność XVIII-wiecznej konwencji literackiej, zgodnie z którą wcześni powieściopisarze stosowali różne techniki, dążąc do nadania swym narracjom cech obiektywizmu i wiarygodności. Ten element powieści nabiera szczególnego znaczenia w odniesieniu do postaci Susan Barton i Piętaszka. Choć na wyspie Defoe nie było kobiet, u Coetzee'ego pojawia się postać Susan Barton ${ }^{40}$, wspóltowarzyszki niedoli obojętnego i okrutnego Kruzo. Po powrocie do Londynu wraz z Piętaszkiem, który, wbrew swemu pierwowzorowi, został zmuszony siłą do podróży ku cywilizacji, pragnie ona sprzedać swoją historię znanemu pisarzowi o nazwisku Foe. Jest to bezpośrednia aluzja do autora Przypadków Robinsona Kruzoe, Daniela Defoe (1660-1731), syna rzeźnika Jamesa Foe, który zmienił nazwisko swego ojca na bardziej szlachecko brzmiące Defoe około roku $1695^{41}$. Oparta na elementach biograficznych postać umykającego przed wierzycielami Foe usiłuje ująć opowieść Susan w ramy interesującej dla czytelników narracji. Elementy fikcji, które Foe wprowadza w narrację Susan, przypisując wagę nieistotnym dla niej elementom, a marginalizując najważniejsze aspekty jej opowieści, budzą jej sprzeciw. Postrzega ona bowiem ingerencję Foe jako zamach na swą autonomię, swoiste uprzedmiotowienie ${ }^{42}$, a od kontroli nad historią swego życia uzależnia swoją wolność jako jednostki ludzkiej.

${ }^{38}$ G. Ch. Spivak, A Critique, s. 179.

39 J. M. Coetzee, op. cit., s. 17.

40 Spivak interpretuje tę postać również w odniesieniu do innej powieści Defoe pt. Roxana (1724), skupiając się na konstrukcji kobiecości w ideologii kapitalistycznej. G. Ch. Spivak, A Critique, s. 180-183.

${ }_{41}$ M. Drabble, J. Stringer, The Concise Oxford Companion to English Literature, Oxford-New York 1987, s. 147.

42 "Nie jestem opowieścią, panie Foe", twierdzi Susan. Coetzee, op. cit., s. 131. 
Piętaszek jest najbardziej enigmatycznym bohaterem w powieści Coetzee'ego - zdecydowanie odbiega od pierwowzoru przepełnionego wdzięcznością „dzikusa”, który z własnej woli podporządkowuje się woli białego człowieka. Jak podkreśla Helen Tiffin, dzieło Defoe odegrało bardzo ważną rolę w popularyzacji obrazów Innego oraz schematów interpretacji kolonialnej obcości ${ }^{43}$. Tymczasem Piętaszkowi Coetzee'ego handlarze niewolników ucięli język, aby pozbawić go możliwości opowiedzenia swojej historii. Niemota Piętaszaka ma wymiar symboliczny - stanowi bowiem metaforę wykluczenia ludów podbitych z oficjalnego dyskursu Historii, zdominowanego przez perspektywę europejskich najeźdźców. Susan, która niczym Robinson w pierwowzorze Defoe na początku powieści pragnie ucywilizować Piętaszka, ucząc go podstawowych słów w języku angielskim, wkrótce pojmuje, że język stanowi narzędzie dominacji, a próby wpojenia obcego języka Piętaszkowi, aby stał się sprawnym i potulnym służącym, świadczą jedynie o odczłowieczeniu ciemnoskórego bohatera w oczach białego człowieka. Piękne, tajemnicze rytuały, którym oddaje się Piętaszek, fascynują Susan, która na próżno usiłuje je zracjonalizować. Porażka, jaką odnosi w swych wysiłkach w celu zrozumienia Piętaszka i odkrycia historii jego życia, uświadamia jej jednak, że Piętaszek ma prawo pozostać niezrozumianym, a wszelkie próby narratywizacji jego losów ponownie, w sposób bardziej symboliczny, pozbawiają go głosu ${ }^{44}$. W tym sensie, jak zauważa Dorota Kołodziejczyk, opowieść, którą konstruuje tytułowy Foe, „jest tyle uzurpacją i fałszerstwem, ile głęboko etyczną transgresją [... ] Powieściopisarz przekłada to, co etyczne - prawdę, czyli Piętaszka z krwi i kości, który nie przedstawia nic poza sobą - na to, co estetyczne, a mianowicie dobrą opowieść" $"$. Ostatnia część powieści, stanowiąca sen narratora (Susan? autora?), w którym miejsce centralne zajmuje wrak statku przewożącego niewolników, podkreśla nieuchwytność i niewypowiadalność losów setek tysięcy zniewolonych istot zatopionych podczas przeprawy przez ocean z Afryki do Ameryki. Z głębi ust Piętaszka

wzbiera powolny strumień: wyplywa bez tchu, bez przerwy. Przepływa wskroś jego ciało i wylewa się na mnie, plynie przez kajutę, plynie przez wrak; omywając urwiska i plaże wyspy, toczy się na północ i na południe aż po krańce ziemi. Miękki i zimny, mroczny i nieskończony bije o moje powieki, o skórę mojej twarzy ${ }^{46}$.

W ostatnich zdaniach powieści Coetzee wyraża w sposób metaforyczny konieczność wsłuchana się w historię Piętaszka, historię, której nie obejmą europejskie systemy wiedzy, gdyż jest to szum pozbawiony słów. W tym sensie tytuł powieści, który, co istotne, znaczy w języku angielskim „wróg”, uwypukla przemoc konceptualną narzuconą ludom podbitym w narracjach kolonizatorów. Mamy tu do czynienia z gestem bardziej radykalnym niż słynna scena w Burzy Szekspira, w której to Kaliban przeklina język wpojony mu przez Prospera. Coetzee polemizuje bowiem z samym systemem reprezentacji charakterystycznym dla kultury europejskiej, z dominacją słowa pisanego i linearnej narracji w świecie zachod-

\footnotetext{
${ }^{43}$ H. Tiffin, Post-colonial Literatures and Counter-discourse, [w:] The Post-colonial Studies Reader, s. 98.

44 Zdaniem Spivak etyczna, otwarta na inność postawa Susan stanowi zaprzeczenie skrajnego indywidualizmu charakterystycznego dla wczesnego kapitalizmu. Ponadto różnica pomiędzy Robinsonem Kruzoe Defoe a Susan Barton Coetzee'ego polega, jej zdaniem, na tym, że Kruzoe, jako typowy kolonizator, pragnie nauczyć Piętaszka „ludzkiej" m o w y , podczas gdy Susan, którą charakteryzuje postawa antyimperialistyczna, pragnie pomóc mu odzyskać g ł o s. G. Ch. Spivak, A Critique, s. 182-187.

45 D. Kołodziejczyk, Postkolonialne, s. 300.

46 J. M. Coetzee, op. cit., s. 159.
} 


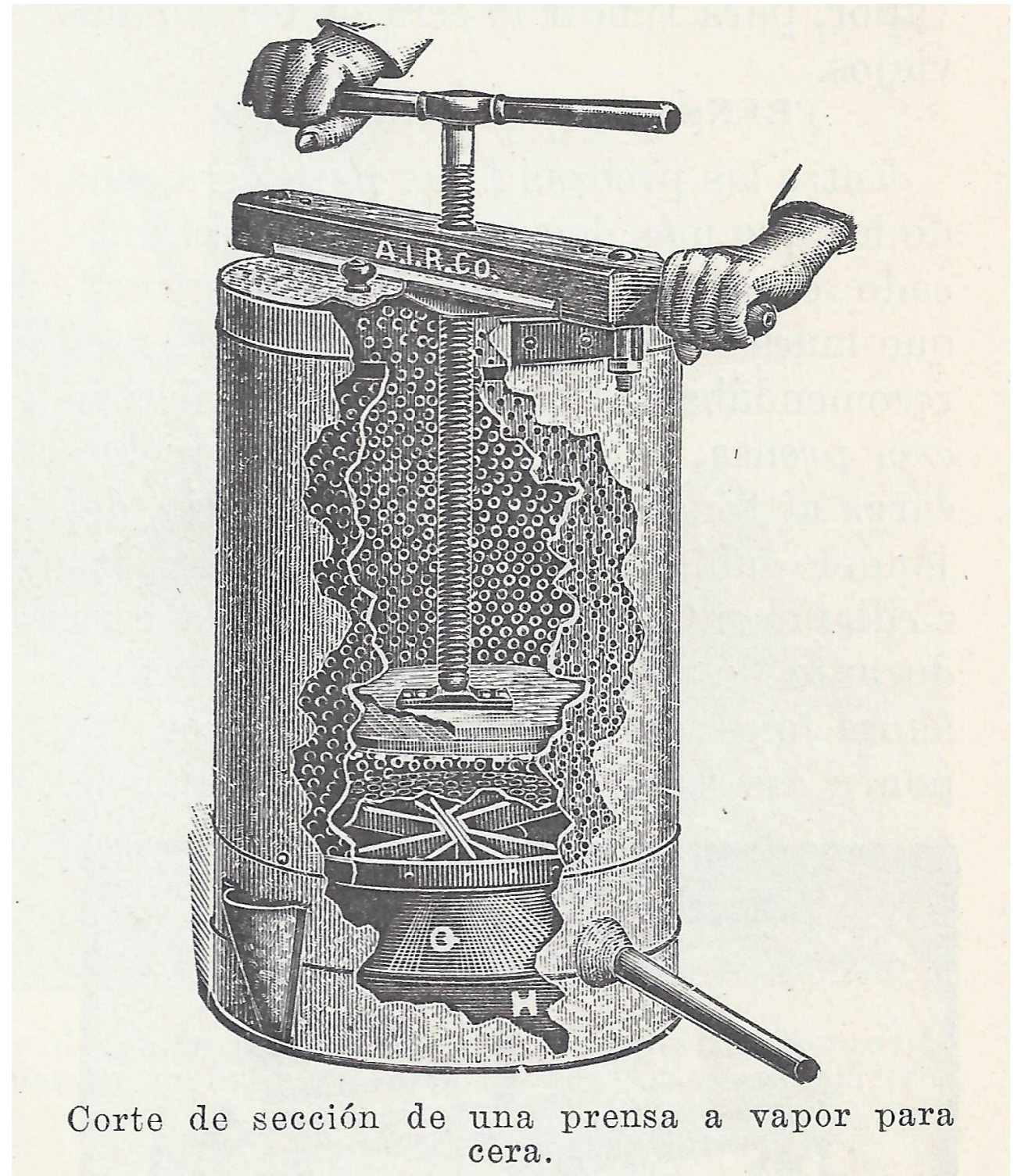

nim. W Foe, jak zaznacza Kołodziejczyk, „problem braku języka (jako widocznego śladu okaleczenia) milczącego bohatera powieści, Piętaszka, lączy się z pytaniem o to, czym jest pamięć bez języka, tożsamość bez pamięci i czy możliwa jest podmiotowość bez pamięci kulturowej" ${ }^{\prime 7}$. Zarazem, zdaniem Spivak, uporczywe milczenie Piętaszka sprawia jednak również, że nie jest on jedynie bezwolną ofiarą kolonializmu; postać ta wymyka się jasnej, koherentnej interpretacji, podważając jednocześnie spójność wielorakich światów przedstawionych w powieści ${ }^{48}$. „Odgłosy wyspy” ${ }^{49}$, które dobywają się z ust Piętaszka, pozostaną

47 D. Kołodziejczyk, Postkolonialne, s. 295.

48 G. Ch. Spivak, A Critique, s. 190-193.

49 J. M. Coetzee, op. cit., s. 158. 
tajemnicą, dopóki nie zmienią się dominujące struktury wyobrażeniowe i kognitywne, co stanowi radykalne, utopijne wyzwanie tekstu Coetzee'ego.

Foe i Szerokie Morze Sargassowe podważają powszechnie przyjętą interpretację tekstów Brontë i Defoe, polemizując przede wszystkim ze sposobem reprezentacji podbitych ludów i stworzonych przez nie kultur. W tym sensie powieści te stanowią przykład tzw. canonical counter discourse, kanonicznego „przeciwdyskursu”. Terminem tym Helen Tiffin określa dzieła postkolonialne oparte na przywłaszczeniu sobie dominujących tekstów europejskich przez pisarzy postkolonialnych i „przepisaniu” ich wbrew obowiązującym w nich kodom ${ }^{50}$. Tiffin podkreśla wagę intertekstualnego dialogu z klasyką, twierdząc, że stanowi on polemikę z szeroko pojętym polem dyskursywnym, w którym teksty te zaistniały i nadal istnieją we współczesnym świecie ${ }^{51}$. Perspektywa komparatystyczna, będąca inspiracją pisarzy zafascynowanych tradycją, udziela się również czytelnikowi, który wpisuje własne znaczenia, porównując dzieła współczesne $\mathrm{z}$ ich pierwowzorami. Tego typu lektura umożliwia krytyczne zrozumienie ideologii kształtujących dyskursy historyczne i kulturowe ${ }^{52}$. Porównania narzucające się przy lekturze „przepisanej” klasyki sugerują jednak, że niezależnie od tego, jak bardzo pisarze postkolonialni dystansują się wobec tradycji literatury europejskiej, nadając bohaterom i światom przedstawionym zupełnie inny wymiar, uwypuklając różnice na tle drugoplanowych podobieństw, klasyka kolonialna stanowi nadal punkt odniesienia dla tekstu postkolonialnego, co podkreśla jej wartość i rangę w świecie literatury globalnej ${ }^{53}$. Problem ten wskazuje na nieodzowną „kontaminację” kultury postkolonialnej przez kulturę metropolii, a w szerszym znaczeniu, na globalną cyrkulację obrazów i porównań we współczesnym świecie.

\section{Konkluzje: (nie)przekładalność kultur}

Komparatystyka w badaniach postkolonialnych jest zatem zadaniem kontrowersyjnym, etycznie niejednoznacznym. Uwypukla zmienne procesy wpływające na kształtowanie wartości twórczości literackiej: wszak Rhys, jako kreolska emigrantka w Europie pierwszej połowy XX wieku, pozostała autorką niedocenioną do lat sześćdziesiątych, natomiast Coetzee, biały pisarz z Południowej Afryki, który zaczął publikować w latach siedemdziesiątych ubiegłego stulecia, zyskał natychmiastową sławę. Porównanie postkolonialne stawia pod znakiem zapytania pojęcie przekładalności kultur i pociąga za sobą zarzut przywłaszczenia kulturowego. To ostatnie funkcjonuje na wielu poziomach: apropriacji wszak może do-

${ }^{50}$ H. Tiffin, op. cit., s. 95-98. Czytelnika polskiego zainteresować mogą inne utwory anglojęzyczne wpisujące się w tę konwencję. Istotnym źródłem polemiki intertekstualnej jest dramaturgia Szekspira (szczególnie Burza i Otello) - odnoszą się do niej w swej twórczości pisarze wywodzący się z Karaibów: George Lamming, V. S. Naipaul, czy też bardziej współcześni Caryl Phillips oraz Elizabeth Nunez. Dzieła sióstr Brontë stanowią ważne interteksty u pisarki z Jamajki Michelle Cliff (np. No Telephone to Heaven) czy Kanadyjki Jane Urquhart (Changing Heaven). Twórczość Josepha Conrada, a w szczególności Jądro ciemności, wywołała liczne kontrowersje w świecie postkolonialnym: „przepisali” ją w sposób mniej lub bardziej radykalny wspomniany V. S. Naipaul (A House for Mister Biswas), karaibski poeta Derek Walcott (The Fortunate Traveller) oraz Kanadyjczyk Timothy Findley (The Headhunter).

51 H. Tiffin, op. cit., s. 98.

52 Do podobnego wniosku dochodzi D. Kołodziejczyk, analizując "etos pamięci postkolonialnej” w powieściach Foe Coetzee'ego oraz Toni Morrison Umiłowana. D. Kołodziejczyk, Postkolonialne, s. 301.

53 Zob. również D. Kołodziejczyk, Wojna, s. 78. 
konać autor postkolonialny, „przepisując” klasyczne dzieła kultury europejskiej, czytelnik europejski przeprowadzając eurocentryczną interpretację dzieła postkolonialnego, czy też autor o korzeniach europejskich opisujący obce mu kultury. Warto tu wspomnieć o radykalnej postawie nigeryjskiego pisarza Chinui Achebego, który w słynnym wykładzie z 1975 roku potępił Jądro ciemności, odmawiając powieści rangi arcydzieła ze względu na naznaczony, jego zdaniem, rasizmem portret Afrykańczyków przedstawiony przez Conrada ${ }^{54}$. W tak ekstremalnej perspektywie kultur nie należy porównywać, gdyż ludzką percepcję zawsze kształtują określone kody kulturowe. Choć postawa Achebego wydaje się dziś zbyt nieprzejednana, podkreśla ona ambiwalentne zaplecze etyczne badacza postkolonialnego.

Czy komparatystyka postkolonialna wzbogaca zatem proces interpretacji czy raczej wskazuje na kulturowe uwikłania krytyka, których przezwyciężyć nie można, gdyż stanowią o samoświadomości badacza? Choć nasze własne uprzedzenia pozostaną dla nas na zawsze nie w pełni uchwytne, obcość innej kultury może nam uzmysłowić ograniczenia tradycji, które nas ukształtowały. Co więcej, z postmodernistycznego punktu widzenia samo pojęcie przywłaszczenia kulturowego pozbawione jest sensu. W dobie globalnego upłynnienia procesów kulturowych, cyrkulację lokalnych treści - mitów, obyczajów czy też porównań - można ponadto uznać za zjawisko pozytywne, jeśli przyjmiemy tezę o deterytorializacji kultur. Myślenie o kulturze bez przestrzeni, promowane przez współczesnego antropologa Arjuna Appaduraia ${ }^{55}$, pozwala na bardziej twórcze spojrzenie na wyobraźnię i procesy ksztaltowania się wyobrażonych tożsamości dzięki globalnemu obiegowi „uwolnionych” kulturowych zasobów świata. Nasuwa się jednak pytanie, czy nie jest to aby ruch jednostronny, polegający na dyfuzji amerykańsko-europejskich zjawisk kulturowych. Współczesna fascynacja innością, charakterystyczna dla badaczy postkolonialnych, objawiająca się często postawą idealizującą obce kultury i deprecjonująca rodzime tradycje, co stanowi swoiste odwrócenie tez Orientalizmu, nie pomniejsza faktu, że podstawowym mechanizmem poznawczym jest nadal porównanie, które określa pewne zjawiska kulturowe jako swojskie i znane (i na przykład nieciekawe), a inne jako obce i egzotyczne (tzn. fascynujące). Być może to właśnie nieprzekładalność ludzkich doświadczeń powinna stać się przedmiotem badań postkolonializmu ${ }^{56}$. Wywrócenie ustalonych paradygmatów i praktyk konceptualnych może okazać się więc największym wyzwaniem komparatystyki postkolonialnej.

\section{Bibliografia}

Achebe Chinua, An Image of Africa: Racism in Conrad's „Heart of Darkness”, kirbyk.net/hod/image. of.africa.html (dostęp: 22.09.2015).

- Colonialist Criticism, [w: The Post-colonial Studies Reader, red. Bill Ashcroft, Gareth Griffiths, Helen Tiffin, London-New York: Routledge, 1999.

Appadurai Arjun, Nowoczesność bez granic. Kulturowe wymiary globalizacji, tłum. Zbigniew Pucek, Kraków: Universitas, 2005.

Barth John, The Literature of Exhaustion, [w:] The Novel Today: Contemporary Writers on Modern Fiction, red. Malcolm Bradbury, Glasgow: Fontana, 1977.

${ }^{54}$ Ch. Achebe, An Image of Africa: Racism in Conrad's „Heart of Darkness", kirbyk.net/hod/image.of.africa. html (dostęp: 22.09.2015).

55 A. Appadurai, Nowoczesność bez granic. Kulturowe wymiary globalizacji, tłum. Z. Pucek, Kraków 2005.

56 Zob. także D. Kołodziejczyk, Wojna, s. 82. 
Bhabha Homi K., Miejsca kultury, tłum. Tomasz Dobrogoszcz, Kraków: Wydawnictwo Uniwersytetu Jagiellońskiego, 2010.

Bordo Susan, Unbearable Weight: Feminism, Western Culture and the Body, Berkeley-Los AngelesLondon: University of California Press, 1995.

Branach-Kallas Anna, Uraz przetrwania. Trauma i polemika z mitem pierwszej wojny światowej w powieści kanadyjskiej, Toruń: Wydawnictwo Naukowe Uniwersytetu Mikołaja Kopernika, 2014.

Brontë Charlotte, Jane Eyre, Harmondsworth: Penguin Books, 1962 (wyd. polskie: Jane Eyre, thum. Teresa Świderska, Warszawa: Prószyński Media, 2011).

Caruth Cathy, Trauma and Experience: Introduction, [w:] Trauma: Explorations in Memory, red. Cathy Caruth, Baltimore-London: Johns Hopkins University Press, 1995.

Coetzee John Maxwell, Foe, New York: Viking, 1987 (wyd. polskie: Foe, thum. Magdalena Konikowska, Kraków: Znak, 2007).

Craps Stef, Buelens Gert, Introduction: Postcolonial Trauma Novels, „Studies in the Novel” 2008, t. $40, \mathrm{nr} 1 / 2$.

Defoe Daniel, The Life and Adventures of Robinson Crusoe, Harmondsworth: Penguin Books, 1985 (wyd. polskie: Przypadki Robinsona Kruzoe, ttum. Józef Birkenmajer, Wrocław: Wydawnictwo Dolnośląskie, 2002).

Drabble Margaret, Stringer Jenny, The Concise Oxford Companion to English Literature, Oxford-New York: Oxford University Press, 1987.

Gandhi Leela, Teoria postkolonialna. Wprowadzenie krytyczne, tłum. Jacek Serwański, Poznań: Wydawnictwo Poznańskie, 2008.

Gilman Sander L., Black Bodies, White Bodies: Toward an Iconography of Female Sexuality in Late Nineteenth-Century Art, Medicine, and Literature, [w: ",Race”, Writing, and Difference, red. Henry Louis Gates, Jr., Chicago-London: University of Chicago Press, 1986.

JanMohamed Abdul R., The Economy of Manichean Allegory: The Function of Racial Difference in Colonialist Literature, [w:] „Race”, Writing, and Difference, red. Henry Louis Gates, Jr., Chicago-London: University of Chicago Press, 1986.

Jenny Laurent, Strategia formy, tłum. Krystyna i Jerzy Faliccy, „Pamiętnik Literacki” 1988, z. 1.

Kincaid Jamaica, A Small Place, New York: Farrar, Straus, Giroux, 1988.

King Thomas, Godzilla vs. Post-Colonial, [w:] Unhomely States: Theorizing English-Canadian Postcolonialism, red. Cynthia Sugars, Peterborough: Broadview Press, 2004.

Kołodziejczyk Dorota, Postkolonialne odzyskiwanie pamięci: zawłaszczenia, fabulacje, niesamowite dopominanie, [w:] Od pamięci biodziedzicznej do postpamięci, red. Teresa Szostek, Roma Sendyka i Ryszard Nycz, Warszawa: Instytut Badań Literackich PAN, 2013.

- Wojna światów? Postkolonialny kontrapunkt w nowej komparatystyce, „Teksty Drugie” 2014, nr 4.

Kristeva Julia, Potęga obrzydzenia. Esej o wstręcie, tłum. Maciej Falski, Kraków: Wydawnictwo Uniwersytetu Jagiellońskiego, 2007.

Lamming George, The Pleasures of Exile, London: Michael Joseph, 1960.

Lewis Herman Judith, Przemoc. Uraz psychiczny i powrót do równowagi, tłum. Anna i Magdalena Kacmajor, Gdańsk: Gdańskie Wydawnictwo Psychologiczne, 2007.

Loomba Ania, Kolonializm/postkolonializm, tłum. Natalia Bloch, Poznań: Wydawnictwo Poznańskie, 2011.

Macaulay Thomas, Minute on Indian Education, [w:] The Post-colonial Studies Reader, red. Bill Ashcroft, Gareth Griffiths, Helen Tiffin, London-New York: Routledge, 1999.

McClintock Anne, Imperial Leather: Race, Gender and Sexuality in the Colonial Contest, New York-London: Routledge, 1995. 
McLeod John, Beginning Postcolonialism, Manchester-New York: Manchester University Press, 2000. Meyer Susan L., From „Colonialism and the Figurative Strategy of Jane Eyre”, [w:] Post-Colonial Theory and English Literature, red. Peter Childs, Edinburgh: Edinburgh University Press, 1999.

Ngũgĩ wa Thiong'o, Decolonising the Mind: The Politics of Language in African Literature, London: James Currey, 1986.

Phillips Richard, Mapping Men and Empire: A Geography of Adventure, London: Routledge, 1997.

Pratt Mary Louise, Imperialne spojrzenie: pisarstwo podróżnicze a transkulturacja, tlum. Ewa Elżbieta Nowakowska, Kraków: Wydawnictwo Uniwersytetu Jagiellońskiego, 2011.

Rhys Jean, Wide Sargasso Sea, London: Deutsch, 1966 (wyd. polskie - Szerokie Morze Sargassowe, tłum. Maryla Topczewska-Metelska, Kraków: Wydawnictwo Literackie, 1987).

Rothberg Michael, Między Paryżem a Warszawa. Pamięć wielokierunkowa, etyka i odpowiedzialność historyczna, tłum. Tomasz Bilczewski i Anna Kowalcze-Pawlik, [w:] Od pamięci biodziedzicznej do postpamięci, red. Teresa Szostek, Roma Sendyka i Ryszard Nycz, Warszawa: Instytut Badań Literackich PAN, 2013.

Said Edward W., Kultura i imperializm, tłum. Monika Wyrwas-Wiśniewska, Kraków: Wydawnictwo Uniwersytetu Jagiellońskiego, 2009.

— Orientalizm, tłum. Monika Wyrwas-Wiśniewska, Poznań: Zysk i S-ka, 2005.

Slemon Stephen, Unsettling the Empire: Resistance Theory for the Second World, [w:] The Post-colonial Studies Reader, red. Bill Ashcroft, Gareth Griffiths, Helen Tiffin, London-New York: Routledge, 1999.

Spivak Gayatri Chakravorty, A Critique of Postcolonial Reason: Toward a History of the Vanishing Present, Cambridge-London: Harvard University Press, 1999.

- Death of a Discipline, New York-Chichester: Columbia University Press, 2003.

— Komparatystyka ekstremalna, thum. Dorota Kołodziejczyk, „Recykling Idei” 2008, nr 10 (wiosna/ lato).

- Three Women's Texts and a Critique of Imperialism, [w: ] „Race”, Writing, and Difference, red. Henry Louis Gates, Jr., Chicago-London: University of Chicago Press, 1986.

Stepan Nancy Leys, Race and Gender: The Role of Analogy in Science, [w:] Anatomy of Racism, red. David Theo Goldberg, Minneapolis-London: University of Minnesota Press, 1990.

Tiffin Helen, Post-colonial Literatures and Counter-discourse, [w:] The Post-colonial Studies Reader, red. Bill Ashcroft, Gareth Griffiths, Helen Tiffin, London-New York: Routledge, 1999. 


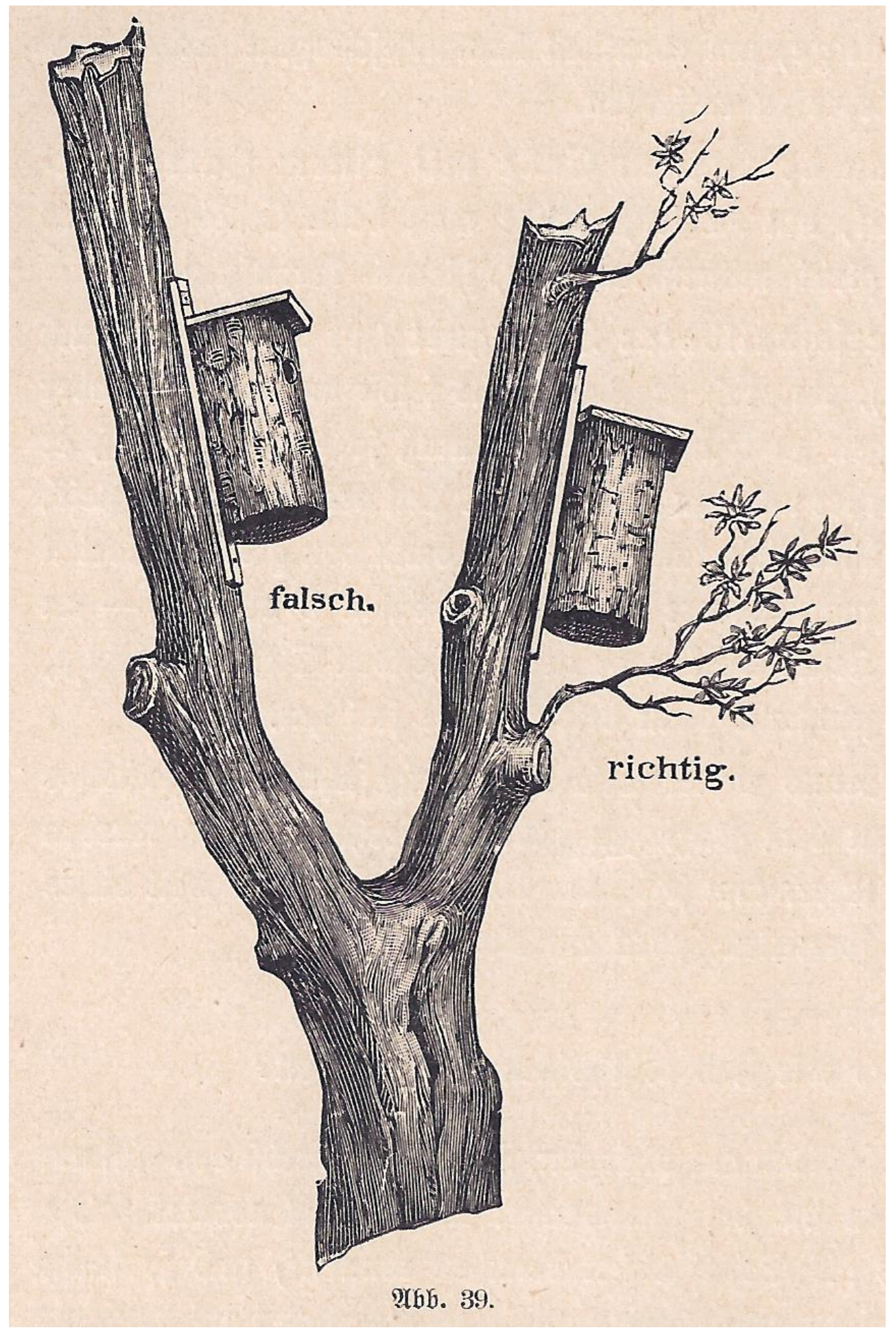

